\title{
Effect of pulsed electric field treatment on shelf life and nutritional value of apple juice
}

\author{
Kinga Dziadek ${ }^{1}$ (D) Aneta Kopeć ${ }^{1} \cdot$ Tomasz Dróżdż $^{2} \cdot$ Paweł Kiełbasa $^{2}$ • \\ Marek Ostafin $^{3} \cdot$ Karol Bulski $^{3} \cdot$ Maciej Oziembłowski $^{4}$
}

Revised: 27 November 2018/Accepted: 9 January 2019/Published online: 7 February 2019

(C) The Author(s) 2019

\begin{abstract}
The aim of this study was to assess shelf life and nutritional value of apple juice, including the content of bioactive compounds, after pulsed electric field (PEF) treatment, taking into account different number of cycles: 4, 6, 8 (total 200, 300, and 400 pulses, respectively). Determination of vitamin $\mathrm{C}$ and polyphenols concentration, antioxidant activity as well as microbiological analysis were conducted immediately after PEF process and after 24, 48 and $72 \mathrm{~h}$ of storage. The results showed that PEF did not affect the content of bioactive compounds. PEF-treated juice did not show changes in the amount of vitamin $\mathrm{C}$ and total polyphenols during the storage for $72 \mathrm{~h}$ under refrigeration. PEF treatment was effective method for inactivation of a wide range of most common food spoilage microorganisms. PEF process can be used as an effective method of food preservation, allowing prolongation of shelf life and protection of nutritional value. This brings
\end{abstract}

Kinga Dziadek

kinga.dziadek@urk.edu.pl

1 Department of Human Nutrition, Faculty of Food Technology, University of Agriculture in Krakow, 122 Balicka St., 30-149 Krakow, Poland

2 Institute of Machinery Management, Ergonomics and Production Processes, Faculty of Production and Power Engineering, University of Agriculture in Krakow, 116B Balicka St., 30-149 Krakow, Poland

3 Department of Microbiology, Faculty of Agriculture and Economics, University of Agriculture in Krakow, 21 Mickiewicza Ave., 31-120 Krakow, Poland

4 Department of Animal Products Technology and Quality Management, Faculty of Biotechnology and Food Sciences, Wroclaw University of Environmental and Life Science, 37 Chełmońskiego St., 51-630 Wroclaw, Poland new opportunities for obtaining safe, healthy and nutritious food.

Keywords Pulsed electric fields · Apple juice ·

Polyphenols · Antioxidant activity $\cdot$ Microorganisms

\section{Introduction}

In recent years, there has been increasing interest in the use of various parts of electromagnetic spectrum in food processing. One of the most promising technology in food industry is pulsed electric field (PEF). During this process, the food sample is treated with high intensity electric field pulses for a short time (microseconds) in a processing chamber (Zeng et al. 2016). Depending on electric conditions, such as electric field strength and number of pulses, PEF treatment can provide different effects and can be used for various applications (Yu et al. 2015).

The PEF technology is usually used in processing liquid products, such as fruit juices, dairy products, liquid eggs and alcoholic beverages, due to ions contained in the liquid, which act as electric charge carriers. This technology is used in various food processes, such as food dehydration, sterilization, extraction, reduction of pesticide residues and inactivation of enzymes (Faridnia et al. 2015; Korma et al. 2016; Yang et al. 2016).

One of the main problem in food industry, especially when it comes to raw materials and semi-finished products, is relatively short shelf life which depends on microbiological stability and natural decay (chemical and physical processes). Spoilage caused by microorganisms is due to the presence of bacteria, yeasts and fungi which use food as a source of carbon and energy to carry out their life processes. Chemical and physical factors, responsible for food 
spoilage, include enzymatic and non-enzymatic reactions, temperature, moisture loss and other chemical changes affecting colour, taste and texture of food (Rawat 2015; Geveke et al. 2015).

Previous results have indicated that the PEF treatment can protect the food products against microbiological spoilage as well as the above-mentioned chemical and physical processes (Evrendilek et al. 2000; Geveke et al. 2015). Additionally the use of PEF technology can preserve or even increase the content of bioactive compounds, mainly polyphenols, increasing the nutritional value and attractiveness of the food products (Min et al. 2003b; Odriozola-Serrano et al. 2009; Medina-Meza and BarbosaCánovas 2015; Leong et al. 2016).

The aim of this study was to evaluate the effect of pulsed electric field treatment on shelf life and nutritional value of apple juice, taking into account different number of pulses. The content of vitamin $\mathrm{C}$ and polyphenols, antioxidant activity as well as spoilage microorganisms' growth in PEF-treated juice were determined after different storage periods.

\section{Materials and methods}

\section{Material}

The research material was $100 \%$ apple juice, naturally unclarified, unpasteurized and unsweetened. The juice was squeezed in a local fruit and vegetable processing company (Małopolska Voivodeship, Poland) and immediately used in analysis. The content of vitamin $\mathrm{C}$, polyphenols and antioxidant activity as well as microorganisms' growth was assessed in fresh and PEF-treated juices. Furthermore, all tests were also carried out after 24,48 , and $72 \mathrm{~h}$ of storage under refrigeration.

\section{PEF system}

PEF treatment was performed using a prototype PEF generator, model ERTEC-SU1 with Line Parameters Analyzer type AS3 Mini. The block diagram of experimental setup is shown in Fig. 1. During the test the analyzer was connected to the power supply line on the lowvoltage side. The treatment chamber with a volume of $20 \mathrm{~mL}$ was made of non-conductive material. The sample was placed between the two parallel stainless steel electrodes with $10 \mathrm{~mm}$ distance. The analyzer was equipped with a three-phase oscilloscope to register the values of voltage and current during the accumulation of energy necessary to trigger the pulse (Fig. 2). The presented waveform indicates that the instantaneous current value, during the energy accumulation, increases from about 0.2
A to $5 \mathrm{~A}$. The measurements of high-voltage pulse waveforms have shown that the voltage range was changed from 4 to $31 \mathrm{kV}$. The recorded waveforms showed oscillating changes of the pulse voltage. A pulse generated by a highvoltage generator exhibited bipolar exponential shape.

\section{PEF treatment}

Apple juice was placed in the treatment chamber between the electrodes. The samples were subjected to cyclic PEF treatment. Each cycle consisted of 50 pulses (one pulse every $30 \mathrm{~s}$ ). The research material was subjected to a different number of cycles: 4, 6, 8 (total 200, 300, and 400 pulses, respectively). Electric field strength was $30 \mathrm{kV} \mathrm{cm}^{-1}$. After one cycle the test sample was cooled in refrigerator at $4{ }^{\circ} \mathrm{C}$ for $15 \mathrm{~min}$ in order to avoid loss of vitamin $\mathrm{C}$ and polyphenolic compounds. Our previous study (unpublished) has indicated that used PEF treatment parameters (frequency of pulses and cycles, the total number of pulses) do not allow temperature of the sample to exceed $35^{\circ} \mathrm{C}$. The temperature was monitored before and during PEF treatment-after each 50 impulses and before the next 50 impulses (after cooling). The temperature of juice before PEF treatment was $12-13{ }^{\circ} \mathrm{C}$, after 50 impulses-31-34 ${ }^{\circ} \mathrm{C}$ and after cooling-11-13 ${ }^{\circ} \mathrm{C}$. Immediately after the PEF process, the juice samples were transferred to sterile tubes in order to determine the level of vitamin $\mathrm{C}$, prepare methanolic extract and conduct the microbiological analysis. The PEF-treated juice was also stored for 24,48 and $72 \mathrm{~h}$.

\section{Determination of bioactive compounds}

The total vitamin $\mathrm{C}$ content (ascorbic acid and dehydroascorbic acid) was measured using Tillmans Method modified by Pijanowski (Fortuna and Rożnowski 2012). The content of total polyphenols and antioxidant activity were assessed in methanolic extracts. The extracts were prepared by mixing $1 \mathrm{~mL}$ of juice with $40 \mathrm{~mL}$ of $70 \%$ methanol (POCh, Gliwice, Poland). The content of total polyphenols was estimated by the Folin-Ciocialteu reagent (Sigma-Aldrich, Saint Louis, MO, USA) (Swain and Hillis 1959). Antioxidant activity was measured by identifying the sample's ability to extinguish an $\mathrm{ABTS}^{+}\left(2,2^{\prime}\right.$-azinobis-(3-ethylbenzothiazoline-6-sulfonic acid) (SigmaAldrich, Saint Louis, MO, USA) free radical (Re et al. 1999).

\section{Microbiological analysis}

The juice samples before the experiment were transferred to a sterile chamber. The chamber was sterilized in an autoclave at $121{ }^{\circ} \mathrm{C}$ for $15 \mathrm{~min}$. After PEF treatment, the 
Fig. 1 The block diagram of experimental setup

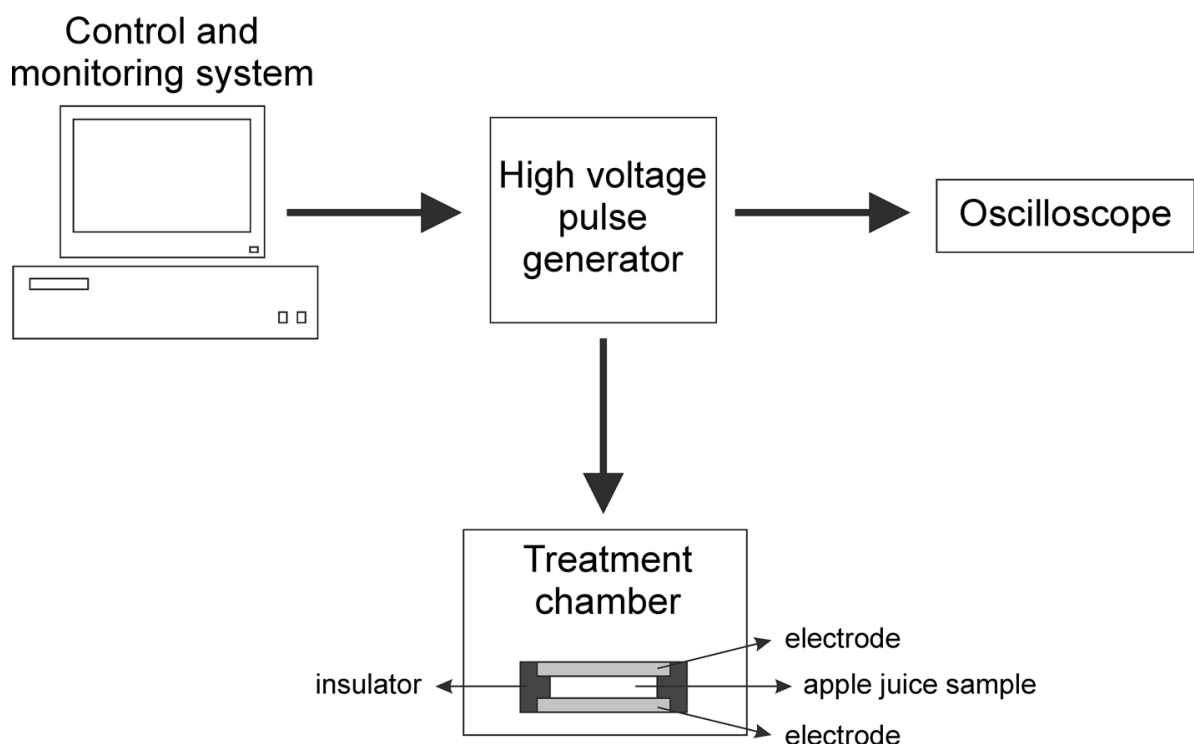

$\mathrm{U}[\mathrm{V}]$

Oscillogram U, I in phase L1

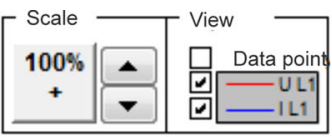

I $[\mathrm{A}]$

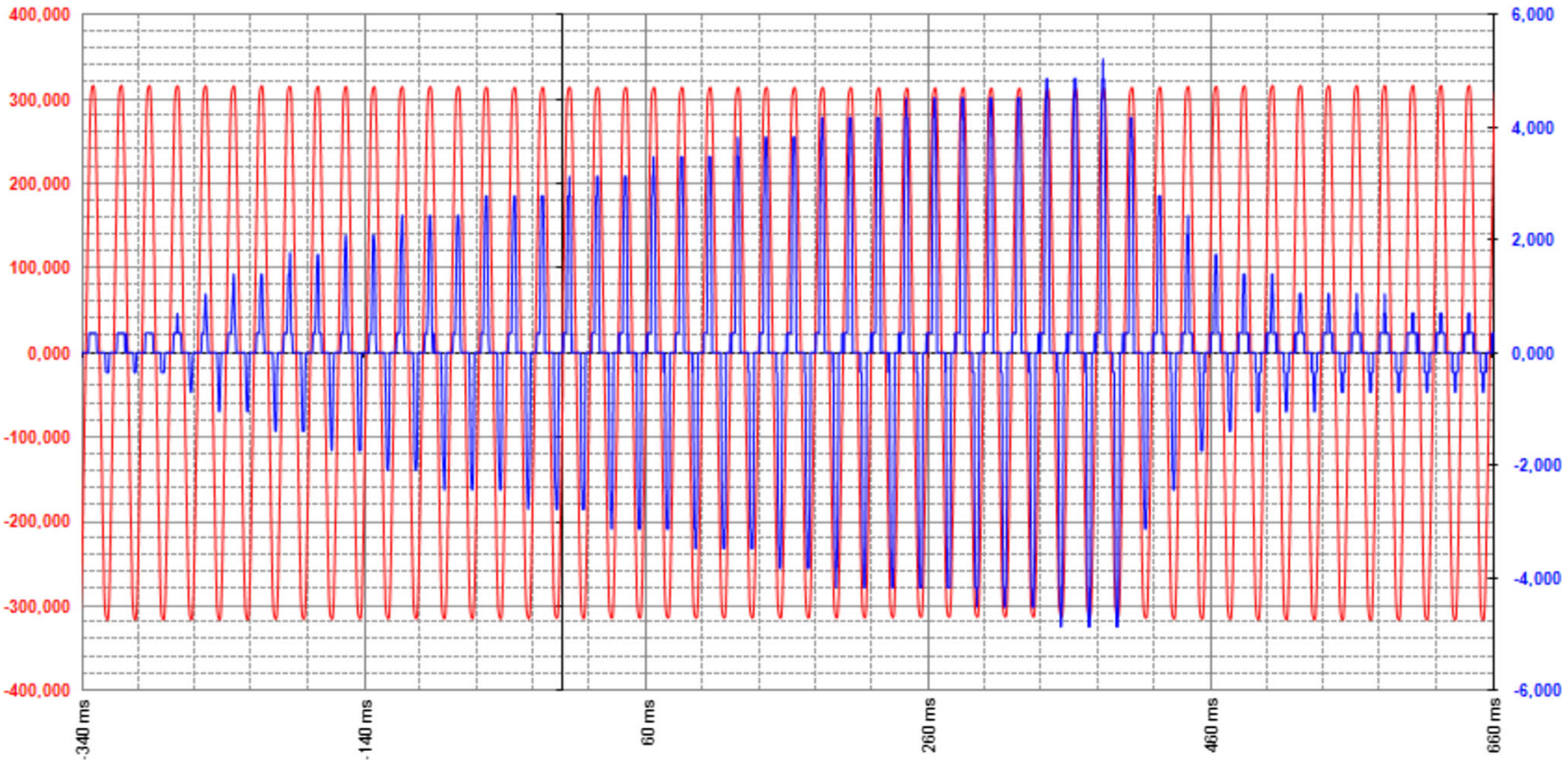

Fig. 2 Oscillogram showing instantaneous values of voltage and current during accumulation of energy to trigger the pulse

chamber was transferred to a laminar hood, where the samples for microbiological analyses were collected.

The research material was analyzed microbiologically using serial dilutions (Koch 1994). All dilutions were prepared using sterile buffered water (Clesceri et al. 1991). Trypic Soy Agar (Biocorp, Warsaw, Poland), Sabouraud Medium (Biocorp, Warsaw, Poland), YPD Medium (Biocorp, Warsaw, Poland), Baird Parker Agar (Sigma-Aldrich, Saint Louis, MO, USA), Stanetz and Bartley Medium
(Merck, Darmstadt, Germany), Endo (Sigma-Aldrich, Saint Louis, MO, USA) and Gauze Medium were used. One milliliter of all dilutions were dispensed into the Petri plates in triplicate. The samples were incubated at $28{ }^{\circ} \mathrm{C}$ (yeasts, fungi, and actinomecetes) for $72 \mathrm{~h}$ and at $35^{\circ} \mathrm{C}$ (bacteria) for $24 \mathrm{~h}$. Plates with 30-300 CFUs per plate were counted (Koch 1994). Finally, the total count was scaled up and the cell counts were expressed as CFUs per beaker volume. 
The total number of the following microorganisms were analyzed: mesophilic, psychrophilic (1) of actinomycetes on the Gauze Medium, the number of fungi on the Sabouraud Medium, yeast on the YPD Medium, coliform on the substrate Endo (2), enterococci on the Stanetz and Bartley Medium (3), the presence of Salmonella (4) and Staphylococcus aureus on Baird-Parker Medium (5). Microorganisms were grown on selective media which were sterilized in a microwave autoclave EnbioJet (Enbio Technology, Dębogórze, Poland).

\section{Statistical analysis}

Results were expressed as the mean \pm SD Differences between samples were analyzed using Duncan's multiple range [Statistica v. 10.0 software (Tulsa, OK, USA)]. $P$ values $<0.05$ were regarded as significant. Correlations between the antioxidant activity and the content of bioactive compounds were examined using Pearson correlation. $P$ values $<0.05$ were regarded as significant.

\section{Results}

The PEF processing, regardless of the number of pulses, did not significantly affect the content of vitamin $\mathrm{C}$ in apple juice (Table 1). What is more, the concentration of vitamin $\mathrm{C}$ in both PEF-treated and untreated juices did not change during the storage under refrigeration.

Furthermore, PEF treatment, regardless of the number of pulses, did not significantly influence the content of total polyphenols in apple juice (Table 1). The concentration of polyphenolic compounds did not change during the storage under refrigeration in PEF-treated juices (except the sample treated by 300 pulses), compared to untreated samples in which the content of polyphenols was reduced.

The results indicated that PEF treatment and also the number of pulses affected antioxidant activity, which decreased just after process and also after $24 \mathrm{~h}$ of storage (except the sample treated by 400 pulses) (Table 1).

The growth of endospores of bacteria, proteolytic bacteria, coliform, fecal streptococcus and actinomycetes in the untreated samples and samples after PEF process was not found. The highest number of mesophilic bacteria, microscopic fungi and yeast was observed in the untreated juice (Table 2). With increasing number of pulses, the reduction in number of studied microorganisms was observed. When 400 pulses were used, total inhibition of growth of mesophilic bacteria, microscopic fungi and yeasts was observed. A statistically significant differences in the number of microorganisms in the untreated sample in comparison to samples after treatment with 200, 300 and 400 pulses were found. There were no significant differences in the number of mesophilic bacteria, microscopic fungi and yeasts, between apple juice treated by 300 and 400 pulses.

The highest average number of mesophilic bacteria was observed in the untreated juice after $72 \mathrm{~h}$ of storage $\left(6586.0 \times 10^{4} \mathrm{cfu} \mathrm{cm}^{-3}\right)$, while the lowest in the juice treated with 300 pulses after $72 \mathrm{~h}\left(248 \mathrm{cfu} \mathrm{cm}^{-3}\right)$ (Fig. 3). The growth of microorganisms in the juices after treatment with 300 and 400 pulses, regardless of the storage period (expect the sample treated with 300 pulses after $72 \mathrm{~h}$ ) was not found. There were no significant differences in the

Table 1 The content of bioactive compounds and antioxidant activity in untreated and PEF-treated apple juice

\begin{tabular}{|c|c|c|c|c|c|}
\hline & \multirow{2}{*}{$\begin{array}{l}\text { Number of } \\
\text { pulses }\end{array}$} & \multicolumn{4}{|l|}{ Storage time } \\
\hline & & $0 \mathrm{~h}$ & After $24 \mathrm{~h}$ & After $48 \mathrm{~h}$ & After $72 \mathrm{~h}$ \\
\hline \multirow[t]{4}{*}{ Vitamin C (mg $\left.100 \mathrm{~mL}^{-1}\right)$} & 0 & $21.61 \pm 2.04 \mathrm{a}$ & $21.61 \pm 2.04 \mathrm{a}$ & $20.17 \pm 0.01 \mathrm{a}$ & $21.61 \pm 2.04 \mathrm{a}$ \\
\hline & 200 & $23.05 \pm 0.01 \mathrm{a}$ & $20.17 \pm 4.08 \mathrm{a}$ & $21.61 \pm 2.04 \mathrm{a}$ & $21.61 \pm 2.04 \mathrm{a}$ \\
\hline & 300 & $21.61 \pm 2.04 \mathrm{a}$ & $21.61 \pm 2.04 \mathrm{a}$ & $21.61 \pm 2.04 \mathrm{a}$ & $20.17 \pm 0.01 \mathrm{a}$ \\
\hline & 400 & $20.17 \pm 0.01 \mathrm{a}$ & $23.05 \pm 0.01 \mathrm{a}$ & $21.61 \pm 2.04 \mathrm{a}$ & $21.61 \pm 2.04 \mathrm{a}$ \\
\hline \multirow{4}{*}{$\begin{array}{l}\text { Total polyphenols } \\
\left(\mathrm{mg} 100 \mathrm{~mL}^{-1}\right)\end{array}$} & 0 & $337.51 \pm 29.18 \mathrm{e}$ & $234.83 \pm 16.77 \mathrm{ab}$ & $232.44 \pm 28.49 \mathrm{a}$ & $234.83 \pm 21.54 \mathrm{ab}$ \\
\hline & 200 & $322.39 \pm 12.64 \mathrm{de}$ & $291.34 \pm 8.27$ abcde & $281.79 \pm 25.61$ abcde & $282.59 \pm 11.29$ abcde \\
\hline & 300 & $340.70 \pm 13.58 \mathrm{e}$ & $272.24 \pm 10.41 \mathrm{abcd}$ & $235.62 \pm 34.80 \mathrm{ab}$ & $254.73 \pm 13.58 \mathrm{abc}$ \\
\hline & 400 & $307.26 \pm 11.29 \mathrm{cde}$ & $300.90 \pm 16.72 \mathrm{cde}$ & $280.88 \pm 28.41$ abcde & $295.66 \pm 22.38$ bcde \\
\hline \multirow{4}{*}{$\begin{array}{l}\operatorname{ABTS}^{+}(\mu \mathrm{mol} \\
\left.\text { Trolox } \mathrm{mL}^{-1}\right)\end{array}$} & 0 & $17.40 \pm 0.45 \mathrm{~h}$ & $12.56 \pm 0.12 \mathrm{a}$ & $12.18 \pm 0.17 \mathrm{a}$ & $12.50 \pm 0.06 \mathrm{a}$ \\
\hline & 200 & $16.17 \pm 0.39 \mathrm{f}$ & $14.58 \pm 0.13 \mathrm{e}$ & $14.44 \pm 0.18 \mathrm{de}$ & $14.46 \pm 0.10 \mathrm{de}$ \\
\hline & 300 & $16.74 \pm 0.52 \mathrm{~g}$ & $13.97 \pm 0.25 \mathrm{bc}$ & $13.61 \pm 0.10 \mathrm{~b}$ & $13.86 \pm 0.16 \mathrm{bc}$ \\
\hline & 400 & $14.09 \pm 0.14 \mathrm{~cd}$ & $19.46 \pm 0.17 \mathrm{j}$ & $18.85 \pm 0.14 \mathrm{i}$ & $16.69 \pm 0.33 \mathrm{~g}$ \\
\hline
\end{tabular}

Results are expressed as mean $\pm \mathrm{SD}(\mathrm{n}=3)$. Statistically significant different are indicated by letter code a-j $(P<0.05)$ 
Table 2 The average number of mesophilic bacteria, microscopic fungi and yeasts $\left[\mathrm{cfu} \mathrm{cm}^{-3}\right]$ in untreated and PEF-treated apple juice

\begin{tabular}{llll}
\hline Number of pulses & Mesophilic bacteria & Microscopic fungi & Yeasts \\
\hline 0 & $4450.5 \times 10^{4} \mathrm{c}$ & $993.2 \times 10^{4} \mathrm{c}$ & $396.9 \times 10^{4} \mathrm{c}$ \\
200 & $2441.3 \times 10^{4} \mathrm{~b}$ & $355.4 \times 10^{4} \mathrm{~b}$ & $221.5 \times 10^{4} \mathrm{~b}$ \\
300 & $62 \mathrm{a}$ & $8.1 \mathrm{a}$ & $84.4 \mathrm{a}$ \\
400 & $0 \mathrm{a}$ & $0 \mathrm{a}$ & $0 \mathrm{a}$ \\
\hline
\end{tabular}

Results are expressed as mean. Statistically significant different are indicated by letter code a-c $(P<0.05)$

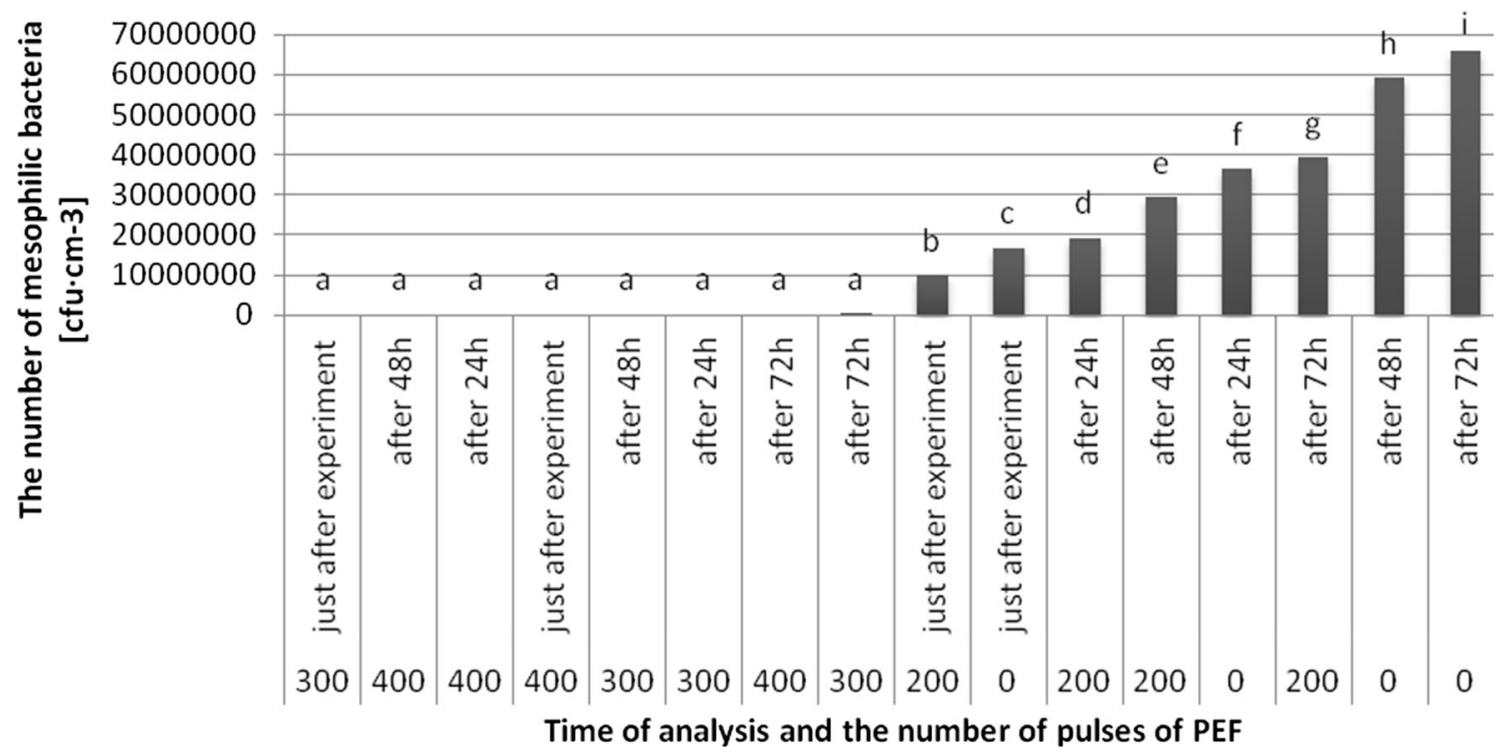

Fig. 3 Evolution of average number of mesophilic bacteria $\left(\mathrm{cfu} \mathrm{cm}^{-3}\right)$ after using PEF with lapse of time after experiment

number of mesophilic bacteria in the apple juice treated with 300 and 400 pulses, regardless of the storage period. The results showed significantly higher number of mesophilic bacteria in the untreated sample compared to the juice treated with 200 pulses, after the same storage periods.

The highest average number of microscopic fungi was found in the untreated apple juice after $72 \mathrm{~h}$ of storage $\left(267.7 \times 10^{4} \mathrm{cfu} \mathrm{cm}^{-3}\right)$, while and the lowest in juice after treatment with 300 pulses after $72 \mathrm{~h}\left(33 \mathrm{cfu} \mathrm{cm}^{-3}\right)$ (Fig. 4). The growth of microorganisms in samples treated with 300 and 400 pulses, regardless of the storage period (expect the juice treated with 300 pulses after $72 \mathrm{~h}$ of storage) was not observed. The results showed a nonsignificant differences in the number of microscopic fungi in the apple juice after treatment with 300 and 400 pulses, regardless of the storage time. The results also revealed nonsignificant differences in the number of microscopic fungi between untreated sample and sample treated with 200 pulses just after the PEF treatment.

The highest average number of yeasts was found in the untreated sample after $72 \mathrm{~h}\left(101.8 \times 10^{4} \mathrm{cfu} \mathrm{cm}^{-3}\right)$, while the lowest in juice treated with 300 pulses after $72 \mathrm{~h}$ $\left(338 \mathrm{cfu} \cdot \mathrm{cm}^{-3}\right.$ ) (Fig. 5). The growth of yeasts in samples treated with 300 and 400 pulses, regardless of the storage time (expect the apple juice treated with 300 pulses after $72 \mathrm{~h}$ ) was not observed. The obtained results indicated a nonsignificant differences in the number of yeasts in the samples after treatment with 300 and 400 pulses, regardless of the storage time. The results also showed nonsignificant differences in the number of yeasts in untreated apple juice in comparison to juice treated with 200 pulses just after the PEF treatment and after $24 \mathrm{~h}$ of storage. Number of yeasts in the untreated samples after 48 and $72 \mathrm{~h}$ of storage was higher than in the samples treated by 200 pulses after the same storage time.

\section{Discussion}

The similar results concerning the vitamin $\mathrm{C}$ content directly after PEF processing were obtained by Evrendilek et al. (2000) in apple juice, Min et al. (2003a) in orange juice and Min et al. (2003b) in tomato juice. Furthermore, Evrendilek et al. (2000) reported that vitamin C content in PEF-treated apple juice did not change during storage at $4{ }^{\circ} \mathrm{C}$ and $22{ }^{\circ} \mathrm{C}$. In contrast, the other authors showed that the content of vitamin $\mathrm{C}$ in the orange and orange-carrot 


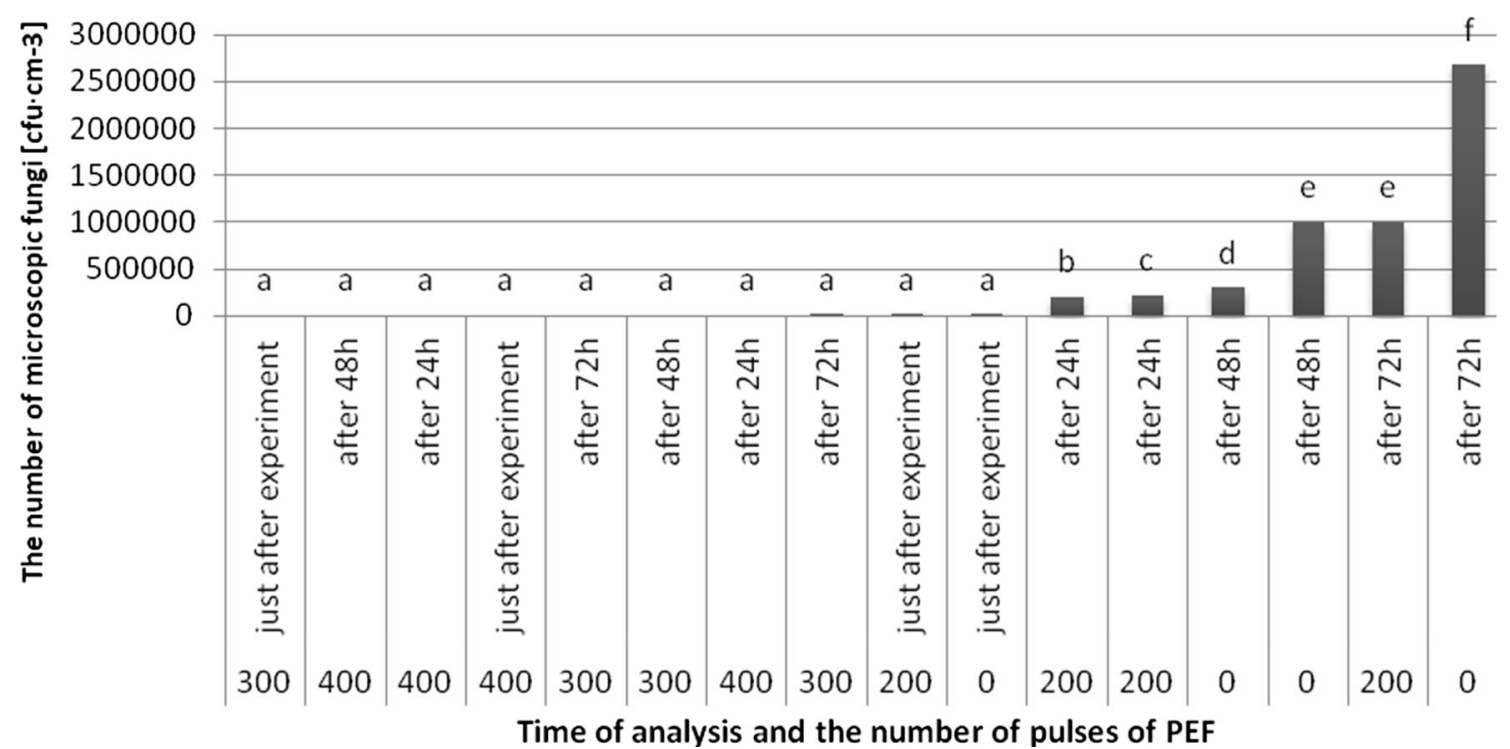

Fig. 4 Evolution of average number of microscopic fungi $\left(\mathrm{cfu} \mathrm{cm}^{-3}\right)$ after using PEF with lapse of time after experiment

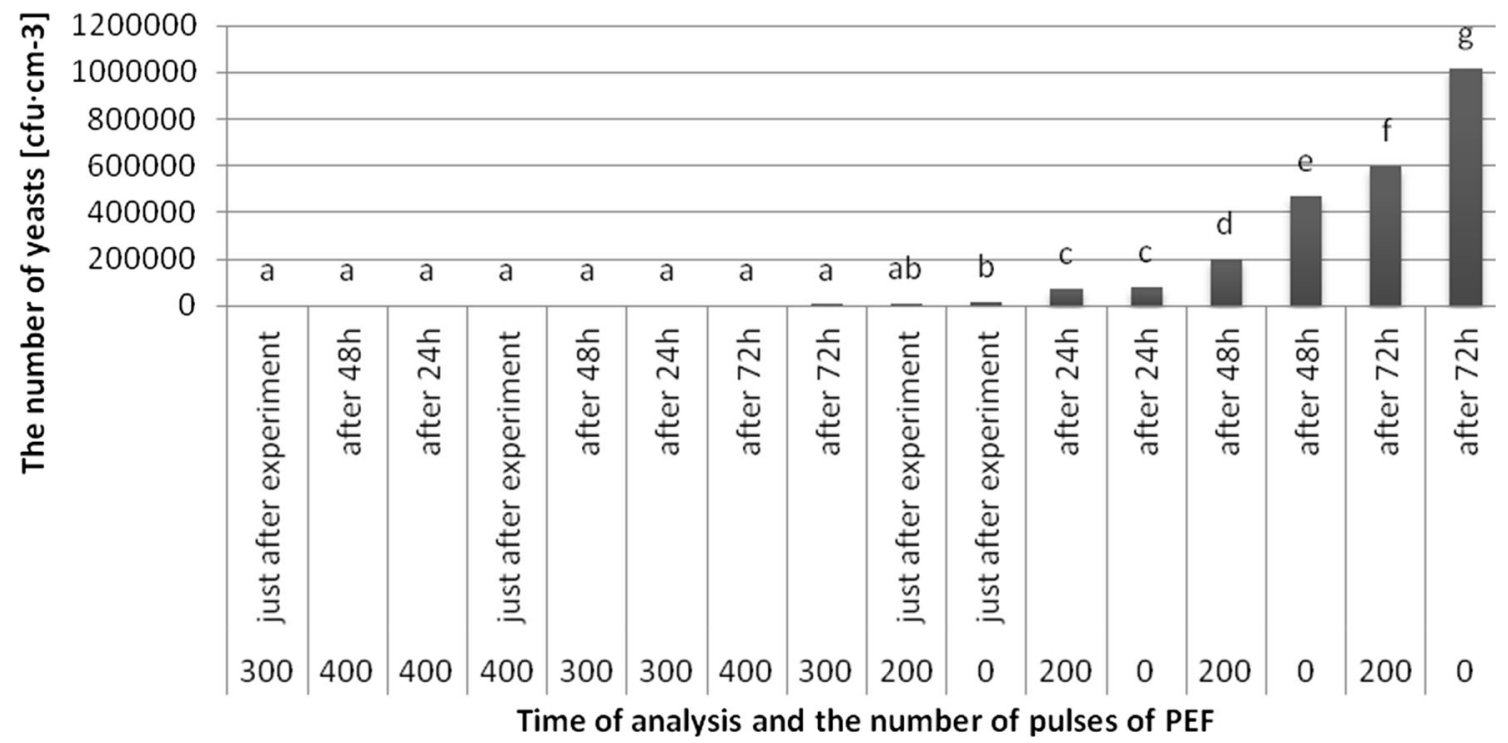

Fig. 5 Evolution of average number of yeasts $\left(\mathrm{cfu} \mathrm{cm}^{-3}\right)$ after using PEF with lapse of time after experiment

juices decreased after storage (Min et al. 2003a; Torregrosa et al. 2006). Ascorbic acid is a heat-sensitive compound and the high temperature causes a loss of this nutrient. The lack of differences in vitamin $\mathrm{C}$ content between fresh and PEF-treated juice may be due to the low processing temperature (Min et al. 2003b; Elez-Martínez and MartínBelloso 2007). Furthermore, the apple juice has a low pH in the range of 3.5-4.5. The acidic environment has shown to preserve the vitamin C (Odriozola-Serrano et al. 2009). Ascorbic acid can be stabilized by PEF processing which is related with inactivation of enzyme-ascorbate oxidase that catalyse vitamin $\mathrm{C}$ oxidation in fruit juices (Oms-Oliu et al. 2009).
The studies have suggested that PEF treatment may also inactivate also other enzymes, such as polyphenoloxidase and peroxidase, therefore phenolic compounds can be preserved (Bi et al. 2013; Sánchez-Vega et al. 2015). No significant differences in content of polyphenolic compounds in tomato juices just after PEF treatment were observed by Odriozola-Serrano et al. (2009). AguilarRosas et al. (2007) reported that the concentration of these compounds in tested apple juice was reduced. In the literature, PEF process led to increase in the content of total polyphenols in various fruit products (plum and grape peels, grape juice) (Medina-Meza and Barbosa-Cánovas 2015; Leong et al. 2016). 
Other authors have shown different results concerning the antioxidant activity. Bi et al. (2013) as well as ElezMartínez and Martín-Belloso (2007) reported that PEF treatment did not affect the antioxidant capacity of fruit juices. The increase in antioxidant activity after PEF processing was reported by Leong et al. (2016), Oms-Oliu et al. (2009) and Odriozola-Serrano et al. (2009). Statistically significant correlation between the content of vitamin $\mathrm{C}$ and antioxidant activity $(\mathrm{r}=0.3696)$, as well as total polyphenols and antioxidant activity $(\mathrm{r}=0.5453)$ was not found. This data indicate that vitamin $\mathrm{C}$ and polyphenols are not the only compounds in the apple juice which are responsible for scavenging free radicals.

Inactivation of the microorganisms using PEF treatment depends on many parameters of process, i.e. field strength, length and shape of the impulse, total duration of impact, temperature and treatment time. Furthermore, selected parameters may affect each other thus it is difficult to compare the results obtained by other authors (Evrendilek and Zhang 2003). In general, the effectiveness of microorganisms inactivation increases with increasing electric field strength, temperature, treatment time and number of pulses (Buckow et al. 2013).

The literature data indicate that the main reason for cell death after PEF treatment is the formation of pores in cell membranes, known as electroporation. Mechanisms of pore formation are not clearly explained (McElhatton and Marshall 2007). One of the explanation is proposed by Zimmermann et al. (1974). During PEF process, free charges of opposite charge are accumulated on the outer and inner surfaces of cell membrane, thus the membrane is compressed. While the external electric field is higher than critical value, the pores are formed. The electric field strength and the treatment time affect pores size and their amount (Zimmermann et al. 1974; Mañas and Pagán 2005).

\section{Conclusion}

The results showed that pulsed electric field technology did not affect the content of bioactive compounds in apple juice. What is more, PEF-treated juice did not show changes in the amount of vitamin $\mathrm{C}$ and total polyphenols during the storage for $72 \mathrm{~h}$ under refrigeration. PEF treatment of apple juice was effective method for inactivation of a wide range of most common food spoilage microorganisms, such as mesophilic bacteria, microscopic fungi and yeasts. However, there was limited number of pulses that ensure effective inactivation of these microorganisms. The use of 400 pulses allows one to store the juice for $72 \mathrm{~h}$ under refrigeration, while the treatment with 300 pulses ensures microbiological stability for $48 \mathrm{~h}$.
To conclude, PEF process can be used as an effective method of food preservation, allowing prolongation of shelf life and protection of nutritional value. This brings new opportunities for obtaining safe, healthy and nutritious food.

Acknowledgements The study was financed by Ministry of Science and Higher Education of the Republic of Poland.

Open Access This article is distributed under the terms of the Creative Commons Attribution 4.0 International License (http://crea tivecommons.org/licenses/by/4.0/), which permits unrestricted use, distribution, and reproduction in any medium, provided you give appropriate credit to the original author(s) and the source, provide a link to the Creative Commons license, and indicate if changes were made.

\section{References}

Aguilar-Rosas SF, Ballinas-Casarrubias ML, Nevarez-Moorillon GV et al (2007) Thermal and pulsed electric fields pasteurization of apple juice: effects on physicochemical properties and flavour compounds. J Food Eng 83:41-46. https://doi.org/10.1016/J. JFOODENG.2006.12.011

Bi X, Liu F, Rao L et al (2013) Effects of electric field strength and pulse rise time on physicochemical and sensory properties of apple juice by pulsed electric field. Innov Food Sci Emerg Technol 17:85-92. https://doi.org/10.1016/J.IFSET.2012.10.008

Buckow R, Ng S, Toepfl S (2013) Pulsed electric field processing of orange juice: a review on microbial, enzymatic, nutritional, and sensory quality and stability. Compr Rev Food Sci Food Saf 12:455-467. https://doi.org/10.1111/1541-4337.12026

Clesceri LS, Greenberg AE, Trussell RR (1991) Standard methods for the examinations of water and waste water, 19th edn

Elez-Martínez P, Martín-Belloso O (2007) Effects of high intensity pulsed electric field processing conditions on vitamin $\mathrm{C}$ and antioxidant capacity of orange juice and gazpacho, a cold vegetable soup. Food Chem 102:201-209. https://doi.org/10. 1016/J.FOODCHEM.2006.04.048

Evrendilek GA, Zhang Q (2003) Effects of pH, temperature, and prepulsed electric field treatment on pulsed electric field and heat inactivation of Escherichia coli O157:H7. J Food Prot 66:755-759

Evrendilek GA, Jin Z, Ruhlman K et al (2000) Microbial safety and shelf-life of apple juice and cider processed by bench and pilot scale PEF systems. Innov Food Sci Emerg Technol 1:77-86. https://doi.org/10.1016/S1466-8564(99)00004-1

Faridnia F, Burritt DJ, Bremer PJ, Oey I (2015) Innovative approach to determine the effect of pulsed electric fields on the microstructure of whole potato tubers: use of cell viability, microscopic images and ionic leakage measurements. Food Res Int 77:556-564. https://doi.org/10.1016/J.FOODRES.2015.08. 028

Fortuna T, Rożnowski J (2012) Wybrane zagadnienia $\mathrm{z}$ chemii żywności: skrypt do ćwiczeń. Wydawnictwo Uniwersytetu Rolniczego, Kraków

Geveke DJ, Aubuchon I, Zhang HQ et al (2015) Validation of a pulsed electric field process to pasteurize strawberry purée. J Food Eng 166:384-389. https://doi.org/10.1016/J.JFOODENG. 2015.05.008

Koch AL (1994) Growth measurement. In: Gerhardt P (ed) Methods for general and molecular bacteriology. ASM Press, Washington, DC 
Korma SA, Kamal-Alahmad, Ali AH et al (2016) Application of pulsed electric field technology in apple juice processing. Austin J Nutr Food Sci 4:1080-1085

Leong SY, Burritt DJ, Oey I (2016) Evaluation of the anthocyanin release and health-promoting properties of Pinot Noir grape juices after pulsed electric fields. Food Chem 196:833-841. https://doi.org/10.1016/J.FOODCHEM.2015.10.025

Mañas P, Pagán R (2005) Microbial inactivation by new technologies of food preservation. J Appl Microbiol 98:1387-1399. https:// doi.org/10.1111/j.1365-2672.2005.02561.x

McElhatton A, Marshall RJ (2007) Food safety: a practical and case study approach. Springer

Medina-Meza IG, Barbosa-Cánovas GV (2015) Assisted extraction of bioactive compounds from plum and grape peels by ultrasonics and pulsed electric fields. J Food Eng 166:268-275. https://doi. org/10.1016/J.JFOODENG.2015.06.012

Min S, Jin ZT, Min SK et al (2003a) Commercial-scale pulsed electric field processing of orange juice. J Food Sci 68:1265-1271. https://doi.org/10.1111/j.1365-2621.2003.tb09637.x

Min S, Jin ZT, Zhang QH (2003b) Commercial scale pulsed electric field processing of tomato juice. J Agric Food Chem 51:3338-3344. https://doi.org/10.1021/jf0260444

Odriozola-Serrano I, Soliva-Fortuny R, Martín-Belloso O (2009) Impact of high-intensity pulsed electric fields variables on vitamin $\mathrm{C}$, anthocyanins and antioxidant capacity of strawberry juice. LWT-Food Sci Technol 42:93-100. https://doi.org/10. 1016/J.LWT.2008.05.008

Oms-Oliu G, Odriozola-Serrano I, Soliva-Fortuny R, Martín-Belloso O (2009) Effects of high-intensity pulsed electric field processing conditions on lycopene, vitamin $\mathrm{C}$ and antioxidant capacity of watermelon juice. Food Chem 115:1312-1319. https://doi.org/ 10.1016/J.FOODCHEM.2009.01.049

Rawat S (2015) Food spoilage: microorganisms and their prevention. Asian J Plant Sci Res 5:47-56

Re R, Pellegrini N, Proteggente A et al (1999) Antioxidant activity applying an improved ABTS radical cation decolorization assay.
Free Radic Biol Med 26:1231-1237. https://doi.org/10.1016/ S0891-5849(98)00315-3

Sánchez-Vega R, Elez-Martínez P, Martín-Belloso O (2015) Influence of high-intensity pulsed electric field processing parameters on antioxidant compounds of broccoli juice. Innov Food Sci Emerg Technol 29:70-77. https://doi.org/10.1016/J.IFSET.2014. 12.002

Swain T, Hillis WE (1959) The phenolic constituents of Prunus domestica. I.-The quantitative analysis of phenolic constituents. J Sci Food Agric 10:63-68. https://doi.org/10.1002/ jsfa. 2740100110

Torregrosa F, Esteve MJ, Frígola A, Cortés C (2006) Ascorbic acid stability during refrigerated storage of orange-carrot juice treated by high pulsed electric field and comparison with pasteurized juice. J Food Eng 73:339-345. https://doi.org/10. 1016/J.JFOODENG.2005.01.034

Yang N, Huang K, Lyu C, Wang J (2016) Pulsed electric field technology in the manufacturing processes of wine, beer, and rice wine: a review. Food Control 61:28-38. https://doi.org/10. 1016/J.FOODCONT.2015.09.022

Yu X, Bals O, Grimi N, Vorobiev E (2015) A new way for the oil plant biomass valorization: polyphenols and proteins extraction from rapeseed stems and leaves assisted by pulsed electric fields. Ind Crops Prod 74:309-318. https://doi.org/10.1016/J. INDCROP.2015.03.045

Zeng F, Gao Q, Han Z et al (2016) Structural properties and digestibility of pulsed electric field treated waxy rice starch. Food Chem 194:1313-1319. https://doi.org/10.1016/J.FOOD CHEM.2015.08.104

Zimmermann U, Pilwat G, Riemann F (1974) Dielectric breakdown of cell membranes. Biophys J 14:881-899. https://doi.org/10. 1016/S0006-3495(74)85956-4

Publisher's Note Springer Nature remains neutral with regard to jurisdictional claims in published maps and institutional affiliations. 